\title{
Assessment of haplotype variation in bovine AMPD1 gene for association with growth and carcass traits in Qinchuan beef cattle
}

\author{
Hua He, Xiaolin Liu, Yulan Gu and Yu Liu \\ College of Animal Science and Technology, Northwest A\&F University, Shaanxi Key Laboratory of Molecular Biology for \\ Agriculture, Yangling, Shaanxi, China
}

\begin{abstract}
The AMPD1 gene plays an important role in the purine nucleotide cycle and energy metabolism in skeletal muscle. In the present study polymorphisms of the AMPD1 gene were detected by PCR-SSCP and DNA sequencing of 215 individuals of the Qinchuan beef cattle breed. DNA sequencing revealed two mutations by comparisons with the bovine genome sequence (acc. no.: NC_007301). Two single nucleotide polymorphisms (SNPs; g.19416T>C and g.19421A $>\mathrm{G}$ ) were detected in intron 11 of the bovine AMPD1 gene. The sequencing of PCR products of animals providing different PCR-SSCP banding patterns showed that four kinds of haplotypes, named: $A(T-A), B(T-G), C(C-A)$ and $D(C-G)$; and the five diplotypes were segregating: AA (T-A/T-A), BC (T-G/C-A or C-G/T-A ), AC (T-A/C-A), CC (C-A/C-A) and CD (C-A/ $(\mathrm{C}-\mathrm{G})$. A significant association of $A M P D 1$ with carcass weight was shown. Animals with the new heterozygote diplotype $B C(P<0.05, n=56)$ had greater carcass weight than those with the other diplotypes. The SNPs in AMPD1 may be used as a possible candidates for markerassisted selection in Qinchuan beef cattle breeding program.
\end{abstract}

Keywords: AMPD1 gene, mutation, haplotype, growth and carcass traits, Qinchuan beef cattle

\section{Zusammenfassung}

\section{Bewertung der Haplotyp Variation bei Rindern AMPD1 Gen für Vereinigung mit Wachstums- und Schlachtleistung in Qinchuan Rinder}

Das AMPD1-Gen spielt eine wichtige Rolle im Purinnukleotid- und Energiestoffwechsel des Skelettmuskels. In dervorliegendenStudiewurden durch PCR-SSCPundDNA-Sequenzierung von 215 Tieren der Fleischrindrasse Qinchuan nach Polymorphismen das AMPD1-Gen detektiert. Das Ergebnis der DNA-Sequenzierung zeigte zwei Mutationen durch Vergleiche mit der genomischen Sequenz des Rindes (acc. no.: NC_007301). Die Polymorphismen (single nucleotide polymorpjhisms, SNPs; g.19416T>C und g.19421A >) wurden im Intron 11 des bovinen AMPD1-Gens nachgewiesen. Die Sequenzierungsergebnisse von PCRProdukten von Tieren mit unterschiedlichen PCR-SSCP- Bandenmustern ergaben, dass vier Haplotypen - A (TA), B (TG), C (CA) und D (CG) - und fünf Diplotypen segregierten: AA (TA/TA ), BC (TG/CA oder CG/TA), AC (TA/CA), CC (CA/CA) und CD (CA/CG). Eine signifikante 
Assoziation von AMPD1 mit dem Schlachtkörpergewicht konnte gezeigt werden. Tiere mit dem neuen heterozygoten Diplotyp $B C(P<0,05, n=56)$ erreichten ein höheres Schlachtgewicht als Tiere mit den anderen Diplotypen. Die SNPs im AMPD1 erweisen sich damit als mögliche Kandidaten für die markergestützte Selektion im Qinchuan-RinderZuchtprogamm.

Schlüsselwörter: AMPD1 Gen, Mutation, Haplotyp, Wachstum und Schlachtleistung, Qinchuan Rinder

\section{Introduction}

Adenosine monophosphate deaminase 1 (AMPD1) is a highly active enzyme in the skeletal muscle that plays an important role in the adenine nucleotide catabolism (Morisaki et al. 1990). Adenosine monophosphate deaminase 1 catalyzes the conversion of adenosine monophosphate to inosine monophosphate. Subsequent cloning of three human genes has revealed the molecular basis for four different isoforms: AMPD1, isoforms M, muscle; AMPD2, isoforms L, liver; AMPD3, isoforms E1 and E2, erythrocyte (Sabina et al. 1990, Bausch et al. 1992, Mahnke et al. 1992, Mahnke et al. 1996). It is likely that the three AMPD genes arose from duplication of a common primordial gene (Morisaki et al. 1990), and subsequently, acquired differences via divergent evolution. Consistent with this hypothesis, AMPD isoforms contain both conserved and divergent domains. The three AMPD polypeptides share a similar 550 amino acid C-terminal end (62-70\% identical) that contains a motif signature sequence believed to be the catalytic center of the enzyme (Chang et al. 1991, Gross et al. 1994). Conversely, each AMPD polypeptide differs by divergent $\mathrm{N}$-terminal sequences of 200 330 amino acids with less than $36 \%$ identity to each other. In addition, differential promoter use and alternative splicing add extensions or substitutions of four (AMPD1), 47-128 (AMPD2) (Mineo et al. 1990, Van et al. 1995), and 7-9 (AMPD3) amino acids at the distal N-terminal end of each AMPD polypeptide. Available information suggests that different $\mathrm{N}$-terminal domains and distal N-terminal variations in each AMPD polypeptide contribute to isoformspecific behaviors of this enzyme (Sabina et al. 2000).

The skeletal muscle-specific isoform (M) of AMPD is encoded by the AMPD1 gene, located on the short arm of chromosome 1 (Sabina et al. 1990). This isoform accounts for more than $95 \%$ of the total AMPD in muscle (Fishbein et al. 1993). It is mainly located in type II muscle fibers particularly at the neuromuscular junction, but also in capillaries (Van et al. 1994).

The porcine AMPD1 gene was mapped to SSC 4q1.6-q2.3 (Stratil et al. 2000). In early studies reported that the porcine AMPD1 maps within known QTL (quantitative trait locus) with effects on carcass traits such as carcass weight, loin and neck meat weight, loin muscle area, shoulder meat weight, ham meat weight, chops weight. Therefore, porcine AMPD1 gene may be an important candidate gene of body measurement and carcass traits and the association results in our study indicated that the SNPs may simply be used as genetic markers linking to quantitative trait loci with effects on carcass traits. Further investigation is required among other populations of pigs to confirm the association between the PCR-ECo81l-RFLP and carcass traits (Wang et al. 2008). The AMPD1 gene might be a candidate gene of meat production trait and provides useful information for further studies on its roles in porcine 
skeletal muscle, etc. Up to now, bovine AMPD1 gene is blank research regarding growth and carcass traits. Therefore, we focus on bovine AMPD1 gene, which could be candidate genes of bovine growth and carcass traits.

At present, no study has revealed any genetic information relevant to bovine AMPD1 gene. The goal of our study was to identify sequence variation of AMPD1 gene in Qinchuan cattle breed, and to analyze the relationship between gene variation and growth and carcass traits.

\section{Materials and methods}

\section{Animal source and DNA preparation}

In this study, a total of 215 beef cattles belonging to Qinchuan (QC) cattle populations, were randomly selected from commercial populations and used in the association analysis. The animals ( $30 \pm 2$ months of age at slaughter) were reared in the province of Shaanxi, China. The records of growth traits (body length, body height, and hip width) and carcass traits (slaughter weight, carcass weight, dressing percentage) were measured according to the criterion $\mathrm{GB} /$ T17238-1998 Cutting Standard of Fresh and Chilled Beef in China (China Standard Publishing House). All experimental procedures were performed according to authorization granted by the Chinese Ministry of Agriculture.

Genomic DNA samples were obtained from 215 beef cattles were isolated from $2 \%$ heparin-treated blood samples and stored at $-80^{\circ} \mathrm{C}$, following the standard procedures (Sambrook et al. 2002).

\section{Primer design and PCR amplification conditions}

Primers used to amplify bovine AMPD1 gene intron 11 locus were designed from a published gene sequence (GenBank acc. no: NC_007301). The sequences of the primers as follows:

\section{F: 5'-AAC CCT CAG GCT CAC CCA-3' (nt 19273-19290);}

R: 5'-GGG CTT AGG GCT CTT GGA -3' (nt 19550-19567).

The size of expected PCR products was $299 \mathrm{bp}$, containing the whole intron 11 and parts of the exon 11 and exon 12 regions.

The $25 \mu \mathrm{L}$ volume contained: $50 \mathrm{ng}$ genomic DNA, $0.5 \mu \mathrm{M}$ of each primer, $1 \times$ Buffer (including $1.5 \mathrm{mM} \mathrm{MgCl}$ ), $200 \mu \mathrm{M}$ dNTPs and 0.625 units of Taq DNA polymerase (MBI). The cycling protocol was 5 min at $95^{\circ} \mathrm{C}, 35$ cycles of $94^{\circ} \mathrm{C}$ for $30 \mathrm{~s}, 60^{\circ} \mathrm{C}$ annealing for $30 \mathrm{~s}, 72^{\circ} \mathrm{C}$ for $30 \mathrm{~s}$, with a final extension at $72^{\circ} \mathrm{C}$ for $10 \mathrm{~min}$.

\section{Single-stranded conformation polymorphism (SSCP)}

Aliquots of $5 \mu \mathrm{L}$ PCR products were mixed with $5 \mu \mathrm{L}$ denaturing solution ( $95 \%$ formamide, $25 \mathrm{mM}$ EDTA, $0.025 \%$ xylene-cyanole, and $0.025 \%$ bromophenol blue), heated at $98{ }^{\circ} \mathrm{C}$ for $10 \mathrm{~min}$, and immediately chilled on ice. Denatured DNA was subjected to $10 \%$ polyacrylamide gel electrophoresis (PAGE) $(80 \times 73 \times 0.75 \mathrm{~mm})$ in $1 \times$ TBE buffer and constant voltage $(200 \mathrm{~V})$ for $2 \mathrm{~h}$ at a constant temperature of $4{ }^{\circ} \mathrm{C}$. The gel was stained with $0.1 \%$ silver nitrate (Zhang et al. 2007). 


\section{DNA sequencing analysis}

The PCR products from different PCR-SSCP genotypes were purified by using the DNA Fragment Purification Kit (BIODEV Corp., Beijing, P. R. China) and sequenced in both directions (Beijing Aolaibo Biotechnology, P. R. China; Applied Biosystems 3730xI DNA sequencer, Foster city, CA, USA); Sequences were analyzed with BioXM software (Version 2.6).

\section{Statistical analysis}

Gene frequencies were determined for Qinchuan cattle breed by direct counting. Chi-square tests (also chi-squared or $\chi^{2}$ test) were used to determine if the individual variant was in Hardy-Weinberg equilibrium. Levels of genetic variability were estimated with the unbiased expected gene homozygosity $\left(\mathrm{H}_{\mathrm{o}}\right)$, gene heterozygosity $\left(\mathrm{H}_{\mathrm{e}}\right)$, the effective allele numbers $(\mathrm{Ne})$, and the polymorphic information content (PIC). The formulas were as follows:

$$
H_{0}=\sum_{i=1}^{n} P_{i}^{2} \quad H_{e}=1-\sum_{i=1}^{n} P_{i}^{2} \quad N_{e}=1 / \sum_{i=1}^{n} P_{i}^{2} \quad P I C=1-\sum_{i=1}^{m} P_{i}{ }^{2}-\sum_{i=1}^{m-1} \sum_{j=i+1}^{m} 2 P_{i}{ }^{2} P_{j}^{2}
$$

where $P i$ is the frequency of the $i$ allele, $n$ is the number of alleles.

The traits were compared between the genotypes of bovine AMPD1 gene. The relationship between genotypes and growth and carcass traits were analysed by the least-squares method as applied in the general linear model (GLM) procedure of the SPSS software (Version 16.0) according to the following linear model (Gan et al. 2008):

$$
Y_{i j k}=\mu+M_{i}+G_{j}+e_{i j k}
$$

where $Y_{i j k}$ is the observed value, $\mu$ is the overall mean for each trait, $M_{i}$ is the fixed effect of $i$-th month of slaughtering, $G_{j}$ is the fixed effect of $j$-th single SNP marker genoetype and $e_{i j k}$ is the random error.

\section{Results and discussion}

\section{Genotype patterns of different polymorphisms}

The polymorphisms of bovine AMPD1 gene were detected by PCR-SSCP and DNA sequencing methods. The results showed that two mutations in intron 11 in Qinchuan cattle breed. The SSCP results showed polymorphic information with five unique SSCP banding patterns observed in Qinchuan cattle population (Figure 1).

In order to better understand the detailed genetic variation within the Chinese bovine AMPD1 gene. The polymorphic DNA amplification fragments were sequenced in both directions. The DNA sequence of the mutation has been submitted to the GenBank database (GQ861240), and mutation sequencing maps of five observed diplotypes are shown in Figure 2. The comparison between nucleotide sequence of bovine AMPD1 gene (GenBank acc.no: NC_007301) and the GQ861240 sequence revealed two mutations: the NC_007301: g. 19416T>C and g. 19421A>G mutations.

Four haplotypes were described as: $A(T-A), B(T-G) C(C-A)$ and $D(C-G)$, respectively (Figure 2). Accordingly, nine diplotypes might be described as: AA (T-A/T-A), BB (T-G/T-G), CC (C-A/C-A), 
DD (C-G/C-G), AB (T-A/T-G), AC (T-A/C-A), AD or BC (T-A/C-G or T-G/C-A), BD (T-G/C-G) and $C D(C-A / C-G)$. With the sequence data from different individuals, the five diplotypes were conflated and described as: AA, BC, AC, CC and CD. These five diplotypes corresponded to five polymorphic patterns found in this study.
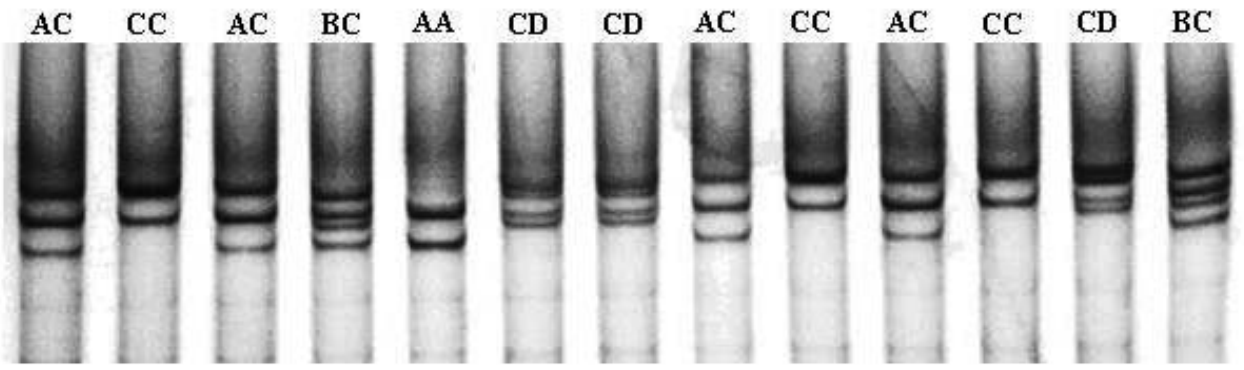

Figure 1

The PCR-SSCP patterns of the bovine AMPD1 gene in $10 \%$ PAGE. Note: Five unique SSCP patterns (AA, BC, AC, CC and CD) were observed in Qinchuan cattle population.
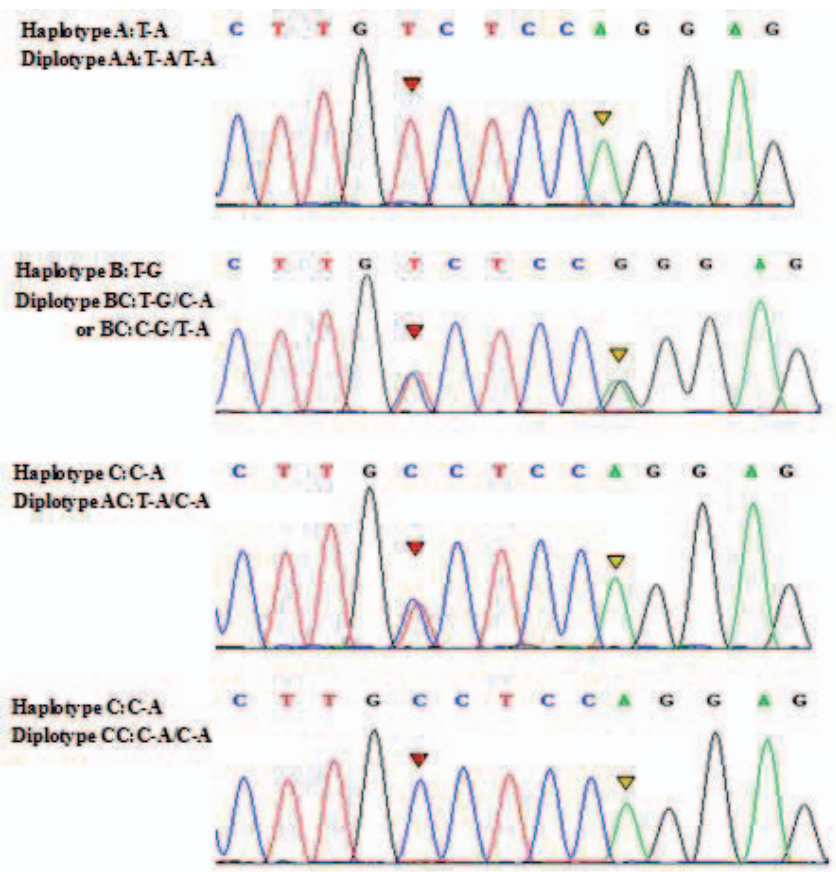

Hapbtype D:C-G

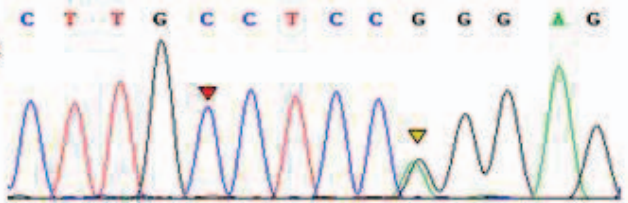

Figure 2

The sequencing

determinations contain two novel mutations (T19416C and A19421G) in bovine AMPD1 gene from different haplotypes and diplotypes. 


\section{Analysis of polymorphism of the AMPD1 gene in Qinchuan cattle breed}

The frequencies of genotypes TT/TC/CC and AA/AG/GG in Qinchuan population were $0.1860 / 0.4791 / 0.3349$ and $0.6186 / 0.3814 / 0.0000$. The frequencies of allele $\mathrm{T} / \mathrm{C}$ and $\mathrm{A} / \mathrm{G}$ of Qinchuan populations were $0.4258 / 0.5744$ and $0.8093 / 0.1097$. In present population, the population genetic parameters of $\mathrm{Ho}, \mathrm{He}, \mathrm{Ne}$ and PIC were presented in Table 1 . According to the classification of $\mathrm{PIC}$ (PIC value $<0.25$, low polymorphism; $0.25<\mathrm{PIC}$ value $<0.5$, intermediate polymorphism; and PIC value $>0.5$, high polymorphism), Qinchuan cattle breed possessed high genetic diversity in two SNPs loci, this reflected that there was a very high genetic diversity within Chinese bovine AMPD1 gene in the analyzed population.

The $\chi 2$-test showed that the genotype distributions of Qinchuan cattle in Hardy-Weinberg equilibrium $(P>0.05)$ at $A 19416 \mathrm{G}$ locus, and disagreement with at Hardy-Weinberg equilibrium $(P<0.05)$ at $\mathrm{A} 19421 \mathrm{G}$ locus, which showed that there was not a dynamic equilibrium even in artificial selection, migration, and genetic drift function at A19421G locus.

Table 1

Genotype frequencies and genetic diversity parameter at the bovine AMPD1 gene

\begin{tabular}{|c|c|c|c|c|c|c|c|c|c|c|}
\hline \multirow[t]{2}{*}{ SNP } & \multicolumn{3}{|c|}{ Genotypic frequencies } & \multirow{2}{*}{\multicolumn{2}{|c|}{ Allelic frequencies }} & \multirow{2}{*}{$\begin{array}{c}\chi^{2} \\
(H W E)\end{array}$} & \multicolumn{4}{|c|}{ Diversity parameter } \\
\hline & & & & & & & $\mathrm{H}_{\mathrm{o}}$ & $\mathrm{H}_{\mathrm{e}}$ & $\mathrm{N}_{\mathrm{e}}$ & PIC \\
\hline \multirow[t]{2}{*}{ T19416C } & TT & TC & CC & $T$ & $\mathrm{C}$ & & & & & \\
\hline & $\begin{array}{c}0.1860 \\
(40 / 215)\end{array}$ & $\begin{array}{c}0.4791 \\
(103 / 215)\end{array}$ & $\begin{array}{l}0.3349 \\
(72 / 215)\end{array}$ & 0.4258 & 0.5744 & $P>0.05$ & 0.5111 & 0.4889 & 1.9557 & 0.3694 \\
\hline \multirow[t]{2}{*}{ A19421G } & AA & AG & GG & A & G & & & & & \\
\hline & $\begin{array}{c}0.6186 \\
(133 / 215)\end{array}$ & $\begin{array}{c}0.3814 \\
(82 / 215\end{array}$ & $\begin{array}{l}0.0000 \\
(0 / 215)\end{array}$ & 0.8093 & 0.1907 & $P<0.05$ & 0.6913 & 0.3087 & 1.4465 & 0.261 \\
\hline
\end{tabular}

$\chi^{2}$ (HWE): Hardy-Weinberg equilibrium $\chi^{2}$ value, $\mathrm{H}_{\mathrm{o}}$ : gene homozygosity, $\mathrm{H}_{\mathrm{e}}$ : gene heterozygosity, $\mathrm{N}_{\mathrm{e}}$ : effective allele numbers, PIC: polymorphism information content.

\section{Association of the five diplotypes with growth and carcass traits in Qinchuan cattle breed}

The association of the five diplotypes in AMPD1 gene with growth and carcass traits (body length, body height, hip width, slaughter weight, carcass weight, and dressing percentage) in Qinchuan cattle ( $n=215)$ were analyzed (Table 2). Individuals with $B C$ was significantly associated with carcass weight $(P=0.049, P<0.05 ; \mathrm{n}=56)$. The animals with $\mathrm{BC}$ had greater body length compared with $\mathrm{AA}(P=0.035, P<0.05 ; \mathrm{n}=40)$ and $\mathrm{CD}(P=0.014, P<0.05 ; \mathrm{n}=26)$ were observed, and the $B C$ had greater slaughter weight compared with genotypes $C D(P=0.021$, $P<0.05 ; \mathrm{n}=26)$; the $B C$ cattle had greater carcass weight than $A A(P=0.045, P<0.05 ; \mathrm{n}=40)$, $C C(P=0.015, P<0.05 ; \mathrm{n}=46)$ and $\mathrm{CD}(P=0.016, P<0.05 ; \mathrm{n}=26)$, the $\mathrm{BC}$ diplotype had greater dressing percentage than $\mathrm{AA}(P=0.021, P<0.05 ; \mathrm{n}=40)$. Other growth and carcass traits in the records had no significant association with diplotype studied. Therefore, the presence of two novel mutations in AMPD1 gene might candidate gene that affects growth and carcass traits in Qinchuan cattle.

The previous studies showed that a few SNPs were detected in the AMPD1 gene. Six SNPs were found in animals representing three commercial breeds (Yorkshire, Landrace, and Duroc) and three Chinese breeds (Meishan, Tongcheng \& Qingping) of pigs. Three of the 6 mutations appeared in intronic regions, 1 in exon 11 and 2 in exon 12. The SNP (T426C) 
in the coding region of exon 12 was a synonymous mutation. Association analysis revealed that a SNP (T426C) in the coding region of exon 12 (GenBank acc. no.: EU 606355) of the AMPD1 gene was significantly associated with loin muscle area trait $(P<0.01)$, loin muscle height $(P<0.01)$ and average backfat thickness $(P<0.05)$ (Wang et al. 2008). Walling and Cepica studies reported that the porcine AMPD1 maps within known QTL (quantitative trait locus) with effects on carcass traits such as carcass weight, loin and neck meat weight, loin muscle area, shoulder meat weight, ham meat weight, chops weight. A new mutation was found in exon 5 (G468T). The G468T transversion is dysfunctional and further indicate that AMPD1 alleles harboring this mutation contribute to the high incidence of partial and complete myoadenylate deaminase deficiency in the Caucasian population (Gross et al. 2002).

Both mutations (g. 19416T>C and g. 19421A>G) in bovine AMPD1 were silent mutations, which can not result in the change of amino acid. But recently there were some reports about the effects of the silent mutations on the gene function and phenotype (Komar et al. 2007). A silent polymorphism in the MDR1 gene resulted in substrate specificity change (Kimchi et al. 2007). A silent mutation of goat POU1F1 gene had been found to associate with milk yield and birth weight (Lan et al. 2007). So, it's an interesting work to find out the mechanism for the association between these silent mutations and the growth and carcass traits in Qinchuan beef cattle.

Table 2

Effects ( $P$-value) of polymorphism of the AMPD1 gene on bovine growth and carcass traits

\begin{tabular}{|c|c|c|c|c|c|c|}
\hline \multirow[t]{2}{*}{ Traits } & \multicolumn{5}{|c|}{ Diplotypes (Mean \pm SE) } & \multirow[t]{2}{*}{$P$-value } \\
\hline & $\mathrm{AA}(\mathrm{n}=40)$ & $A C(n=47)$ & $B C(n=56)$ & $C C(n=46)$ & $C D(n=26)$ & \\
\hline $\mathrm{BH}, \mathrm{cm}$ & $\begin{array}{c}139.3077 \pm \\
1.5519\end{array}$ & $\begin{array}{c}138.7143 \pm \\
1.2211\end{array}$ & $\begin{array}{c}141.1333 \pm \\
1.0216\end{array}$ & $\begin{array}{c}139.8947 \pm \\
1.2837\end{array}$ & $\begin{array}{c}139.0769 \pm \\
1.5519\end{array}$ & 0.5916 \\
\hline $\mathrm{BL}, \mathrm{cm}$ & $\begin{array}{c}148.7692 \pm \\
1.7650^{\mathrm{a}}\end{array}$ & $\begin{array}{r}150.0476 \pm \\
1.3887^{\mathrm{ab}}\end{array}$ & $\begin{array}{c}153.3000 \pm \\
1.1619^{b}\end{array}$ & $\begin{array}{c}151.7368 \pm \\
1.4599^{\mathrm{ab}}\end{array}$ & $\begin{array}{c}148.0000 \pm \\
1.7650^{\mathrm{a}}\end{array}$ & 0.0666 \\
\hline $\mathrm{HW}, \mathrm{cm}$ & $\begin{array}{c}46.8462 \pm \\
1.0451\end{array}$ & $\begin{array}{c}46.0714 \pm \\
0.8222\end{array}$ & $\begin{array}{c}46.8333 \pm \\
0.6879\end{array}$ & $\begin{array}{c}46.8684 \pm \\
0.8644\end{array}$ & $\begin{array}{c}48.6153 \pm \\
1.0450\end{array}$ & 0.4500 \\
\hline SW, kg & $\begin{array}{r}491.1538 \pm \\
17.0453^{\mathrm{ab}}\end{array}$ & $\begin{array}{c}499.8095 \pm \\
13.4111^{\mathrm{ab}}\end{array}$ & $\begin{array}{c}509.4000 \pm \\
11.2206^{\mathrm{a}}\end{array}$ & $\begin{array}{r}479.0526 \pm \\
14.0993^{\mathrm{ab}}\end{array}$ & $\begin{array}{c}461.3077 \pm \\
17.0453^{b}\end{array}$ & 0.1552 \\
\hline $\mathrm{CW}, \mathrm{kg}$ & $\begin{array}{c}257.0308 \pm \\
9.9501^{\mathrm{a}}\end{array}$ & $\begin{array}{c}266.6952 \pm \\
7.8287^{\mathrm{ab}}\end{array}$ & $\begin{array}{c}281.2400 \pm \\
6.5500^{\mathrm{b}}\end{array}$ & $\begin{array}{c}255.1263 \pm \\
8.2304^{\mathrm{a}}\end{array}$ & $\begin{array}{c}252.0462 \pm \\
9.9501^{\mathrm{a}}\end{array}$ & 0.0491 \\
\hline$D P, \%$ & $\begin{array}{c}52.3046 \pm \\
1.1444^{\mathrm{a}}\end{array}$ & $\begin{array}{r}53.5028 \pm \\
0.9004^{\mathrm{ab}}\end{array}$ & $\begin{array}{c}55.5149 \pm \\
0.7533^{\mathrm{b}}\end{array}$ & $\begin{array}{r}53.1175 \pm \\
0.9466^{\mathrm{ab}}\end{array}$ & $\begin{array}{c}54.5957 \pm \\
1.1443^{\mathrm{ab}}\end{array}$ & 0.1140 \\
\hline
\end{tabular}

SE: standard error of means, BH: body height, BL: body length, HW: hip width, SW: slaughter weight, CW: carcass weight, DP: dressing percentage

Values with different superscripts within the same line differ significantly at $P<0.05$.

The objectives of the present study were to identify sequence variation in bovine AMPD1 gene and to evaluate associations between the polymorphisms and growth and carcass traits in Qinchuan cattle breed.

In summary, the present study reveals that the polymorphism of the bovine AMPD1 gene is significantly associated with the body length, slaughter weight, carcass weight and dressing percentage, and no significant association with body height in Qinchuan cattle. The genotype $B C$ tends to be better than those with the other genotypes in growth and carcass traits performance. Therefore, the presence of two SNPs of AMPD1 gene might 
influence growth and carcass traits in Qinchuan population. Furthermore, this study will be contributed to geneticists and breeders as a molecular marker for better performance in the bovine industry.

\section{Acknowledgements}

This study was supported by the National "863« Program of China (No. 2008AA101010), »13115« Sci-Tech Innovation Program of Shaanxi Province (2008ZDKG-11).

\section{References}

Bausch-Jurken MT, Mahnke-Zizelman DK, Morisaki T, Sabina RL (1992) Molecular cloning of AMP deaminase isoform L: sequence and bacterial expression of human AMPD2 Cdna. J Biol Chem 267, 22407-22413

Cepica S, Stratil A, Kopecny M, Blazkova P, Schroffel J, Davoli R, Fontanesi L, Reiner G, Bartenschlager H, Moser G, Geldermann H (2003) Linkage and QTL mapping for Sus scrofa chromosome 4. J Anim Breed Genet 120, 28-37

Chang ZY, Nygaard P, Chinault AC, Kellems RE (1991) Deduced amino acid sequence of Escherichia coli adenosine deaminase reveals evolutionarily conserved amino acid residues: implications for catalytic function. Biochemistry 30, 2273-2280

Fishbein WN, Sabina RL, Ogasawara N, and Holmes EW (1993) Immunologic evidence for three isoforms of AMP deaminase (AMPD) in mature skeletal muscle. Biochim Biophys Acta 1163, 97-104

Gan QF, Zhang LP, Li JY, Hou GY, Li HD, Gao X, Ren HY, Chen JB, Xu SZ (2008) Association analysis of thyroglobulin gene variants with carcass and meat quality traits in beef cattle. J Appl Genet 49, 251-255

Gross M, Morisaki H, Morisaki T, and Holmes EW (1994) Identification of functional domains in AMPD1 by mutational analysis. Biochem Biophys Res Commun 205, 1010-1017

Gross M, Rotzer E, Kolle P, Mortier W, Reichmann H, Goebel HH, Lochmuller H, Pongratz D, Mahnke-Zizelman DK, Sabina RL (2002) A G468-T AMPD1 mutant allele contributes to the high incidence of myoadenylate deaminase deficiency in the Caucasian population. Neuromuscular Disorders 12, 558-565

Kimchi-Sarfaty C, Oh JM, Kim IW et al. (2007) A »silent" polymorphism in the MDR1 gene changes substrate specificity. Science 315, 525-528

Komar AA (2007) Silent SNPs: impact on gene function and phenotype. Pharmacogenomics 8, 1075-1080

Lan XY, Pan CY, Chen H et al. (2007) An Alul PCR-RFLP detecting a silent allele at the goat POU1F1 locus and its association with production traits. Small Rumin Res 73, 8-12

Mahnke-Zizelman DK, Sabina RL (1992) Cloning of human AMP deaminase isoform E cDNAs. Evidence for a third AMPD gene exhibiting alternatively spliced 5'-exons. J Biol Chem 267, 20866-20877

Mahnke-Zizelman DK, Van den Bergh F, Bausch-Jurken MT, Eddy R, Sait S, Shows TB, Sabina RL (1996) Cloning, sequence, and characterization of the human AMPD2 gene: evidence for transcriptional regulation by two closely spaced promoters. Biochim Biophys Acta 1308, 122-132

Mineo I, Clarke PR, Sabina RL, Holmes EW (1990) A novel pathway for alternative splicing: identification of an RNA intermediate that generates an alternative 5 ' splice donor site not present in the primary transcript of AMPD1. Mol Cell Biol 10, 5271-5278

Morisaki T, Sabina RL, Holmes EW (1990) Adenylate deaminase. A multigene family in humans and rats. J Biol Chem 265, 11482-11486

Sabina RL, Mahnke-Zizelman DK (2000) Towards an understanding of the functional significance of N-terminal domain divergence in human AMP deaminase isoforms. Pharm Therap 87, 279-283

Sabina RL, Morisaki T, Clarke P, Eddy R, Shows TB, Morton CC, Holmes EW (1990) Characterization of the human and rat myoadenylate deaminase genes. J Biol Chem 265, 9423-9433 
Sambrook J, Russell D (2002) Translated by Huang Pei Tang, Molecular Cloning: A Laboratory Manual. Beijing, China, 468-469

Stratil A, Knoll A, Moser G, Kopecny M, Geldermann H (2000) The porcine adenosine monophosphate deaminase 1 (AMPD1) gene maps to chromosome 4. Anim Genet 31, 147-148

Van den Bergh F, Sabina RL (1995) Characterization of human AMP deaminase 2 (AMPD2) gene expression reveals alternative transcripts encoding variable $\mathrm{N}$-terminal extensions of isoform L. Biochem J 312, 401410

Van Kuppevelt TH, Veerkamp JH, Fishbein WN, Ogasawara N, and Sabina RL (1994) Immunolocalization of AMPdeaminase isozymes in human skeletal muscle and cultured muscle cells: concentration of isoform M at the neuromuscular junction. J Histochem Cytochem 42, 861-868

Walling GA, Visscher PM, Andersson L, Rothschild MF, Wang LZ, Moser G, Groenen MAM, Bidanel JP, Cepica S, Archibald AL, Geldermann H, De Koning DJ, Milan D, Haley CS (2000) Combined analyses of data from quantitative trait loci mapping studies: chromosome 4 effects on porcine growth and fatness. Genetics $155,1369-1378$

Wang LJ, Mo XY, Xu YG, Zuo B, Lei MG, Li FG, Jiang SW, Deng CY, Xiong YZ (2008) Molecular characterization and expression patterns of AMP deaminase1 (AMPD1) in porcine skeletal muscle. Comp Biochem Physiol B Biochem Mol Biol 151, 159-166

Zhang CL, Wang YH, Chen H, Lan X, Lei CZ (2007) Enhance the efficiency of single-strand conformation polymorphism analysis by short polyacrylamide gel and quick low-background silver staining. Annalistic Biochemistry $365,286-287$

Received 21 February 2010, accepted 10 July 2010.

Corresponding author:

Xiaolin Liu

email: liuxiaolin@nwsuaf.edu.cn, hehua686@yahoo.com.cn

College of Animal Science and Technology, Northwest A\&F University, No.22 Xinong Road, Yangling, Shaanxi 712100 , China 